ISSN: 2302-8556

E-Jurnal Akuntansi Universitas Udayana

Vol.25.2.November (2018): 1390-1417

DOI: https://doi.org/10.24843/EJA.2018.v25.i02.p22

\title{
Efektivitas Manajemen Sumber Daya Manusia (Studi Kasus Penerapan Audit Manajemen pada Hotel X Seminyak)
}

\author{
Sony Ricardo Sembiring ${ }^{1}$ \\ Ketut Budiartha ${ }^{2}$
}

${ }^{1}$ Fakultas Ekonomi dan Bisnis Universitas Udayana (Unud), Bali, Indonesia email: sonyricardo652@gmail.com/ Telp: +62 8974772497

${ }^{2}$ Fakultas Ekonomi dan Bisnis Universitas Udayana (Unud), Bali, Indonesia

\begin{abstract}
ABSTRAK
Penelitian ini merupakan penelitian kualitatif dengan pendekatan studi kasus. Tujuan penelitian ini untuk mengetahui efektivitas manajemen sumber daya manusia yang terdapat di Hotel X Seminyak. Pengumpulan data menggunakan metode wawancara dengan informan yang bersifat purposive, observasi dan dokumentasi di lapangan. Instrumen penelitian audit manajemen ini menggunakan program audit sebagai langkah kerjanya dan penilaian efektivitas sebagai teknik analisis datanya. Hasil penelitian menemukan bahwa kegiatan manajemen SDM di Hotel X Seminyak telah berjalan dengan efektif yakni program rekrutmen, pelatihan dan pengembangan, perencanaan dan pengembangan karir, serta pemutusan hubungan kerja. Program lainnya yakni program seleksi dan penempatan, serta kesehatan dan keselamatan kerja tergolong cukup efektif. Sedangkan program perencanaan tergolong kurang efektif. Berdasarkan temuan tersebut disarankan beberapa rekomendasi perbaikan seperti dibuatnya standar perencanaan, penambahan tenaga kerja baru, serta dilaksanakannya sosialisasi tentang pentingnya keselamatan kerja. Rekomendasi-rekomendasi tersebut diberikan dengan harapan kedepannya kegiatan manajemen SDM di Hotel X Seminyak dapat berjalan lebih efektif. Kata kunci: audit manajemen, sumber daya manusia (SDM), efektivitas, program audit
\end{abstract}

\begin{abstract}
This research is a qualitative research with a case study approach. The purpose is to determine the effectiveness of human resource management in $X$ Seminyak Hotel. The data collection used interview with purposive informants, observation and documentation method. This management audit research instrument uses the audit program as a guidelines and effectiveness assessment as analysis technique. The results of the study found that recruitment, training and development, career planning and development, and termination of employment programs at organization had run effectively. The program selection and placement, as well as occupational health and safety are classified as quite effective, while the planning program is classified as ineffective. Based on these findings several recommendations for improvement were suggested such as the establishment of planning standards, the addition of new workforce, and socialization the importance of work safety. These recommendations are given so human resources management activities can run effectively.
\end{abstract}

Keyword: audit management, human resources (HR), effectiveness, audit program

\section{PENDAHULUAN}

Pulau Bali merupakan daerah tujuan wisata yang sangat populer bagi wisatawan domestik maupun wisatawan mancanegara, para investor telah melihat peluang ini 
sebagai suatu kesempatan untuk mengembangkan bisnis mereka dengan membangun hotel-hotel yang berbintang, resort dan juga motel. Salah satu hotel yang terdapat di wilayah Bali ini adalah Hotel X Seminyak, dimana hotel ini berada di kawasan Seminyak yang merupakan wilayah tujuan wisata.

Penelitian efektivitas manajemen sumber daya manusia dengan pendekatan audit manajemen ini ditujukan pada bagian pengendalian SDM, yang dikelola oleh departemen SDM (Human Resources Department) di Hotel X Seminyak. Hotel X Seminyak ini pada saat sekarang belum dapat secara optimal mengelola SDM yang dimiliki. Hal ini dilihat dari masih terdapatnya karyawan yang bekerja secara merangkap, masih terdapatnya karyawan yang bekerja bukan pada bidang yang dikuasainya, terdapatnya karyawan yang bekerja melebihi waktu yang seharusnya sehingga karyawan harus kerja lembur (over time), terdapatnya karyawan yang mengundurkan diri sebelum kontrak selesai sehingga perusahaan harus melakukan pemutusan hubungan kerja. Masalah-masalah yang terdapat dalam manajemen ini merupakan faktor yang mendukung peneliti dalam meneliti pengelolaan sumber daya manusia di Hotel X Seminyak.

Proses penerapan manajemen SDM bukanlah hal yang mudah untuk diterapkan, mengingat bahwa jumlah SDM yang terdapat di dalam suatu organisasi sangatlah banyak jumlahnya, disamping itu perbedaan kepentingan antara satu individu dengan dengan individu lainnya tentu memiliki perbedaan. Praktik managemen sumber daya manusia bukan hanya dipilih berdasarkan teknisnya, tetapi juga harus mempertimbangkan bagaimana implementasi strategi organisasi (Schuler dan Jackson, 2014). Suatu kebijakan yang diterapkan oleh 
manajemen sumber daya manusia ketika tidak dapat diterima oleh tenaga kerja akan berakibat pada munculnya keluhan dan mungkin saja pada akhirnya akan berujung pada pemutusan hubungan kerja. Keluhan dapat berarti tuntutan dari karyawan bahwa manajemen tidak bertindak menurut dan memenuhi syarat-syarat persetujuan manajememen tenaga kerja yang telah dinegosiasikan, sesuai dengan bagaimana mereka menerimanya (Nickels, James M., dan Susan, 2010). Oleh karena itu pada saat sekarang manager sumber daya manusia menghadapi tantangan yang berat dalam menerapkan kebijakan yang dibuat, bukan hanya karena keluhan dari pekerja tetapi manager SDM juga harus dapat menyeimbangkan anatara lingkungan bisnis dan menyusunnya sesuai dengan tujuan organisasi dan individu (Mahajan, 2015).

Penelaaan mengenai kebijakan - kebijakan yang telah dibuat manajemen sumber daya manusia dapat dievaluasi dengan menggunakan suatu sistem yang disebut dengan audit manajemen (Ukil, 2015). Audit manajemen dapat berarti evaluasi terhadap efisiensi dan efektivitas operasi perusahaan yang harus dipertanggung jawabkan kepada pihak yang memiliki wewenang yang lebih tinggi melalui proses pelaporan mengenai bagaimana suatu sumber daya dan dana telah digunakan secara efisien (Wulandari, Rasyidi, dan Rachman, 2017).

Audit atas fungsi sumber daya manusia merupakan penilaian dan analisis yang komprehensif terhadap program - program sumber daya manusia, secara khusus audit ini dilakukan pada departemen sumber daya manusia, tetapi tidak terbatas hanya pada aktivitas yang terjadi pada departemen ini (Maharani dan Sari, 2014). Audit manajemen SDM terfokus pada pencarian informasi dan 
permasalahan perusahaan dari sudut pandang SDM, dan jika ditinjau lebih dalam audit SDM menyangkut proses identifikasi permasalahan yang menyebabkan kegagalan perusahaan dan kemudian dilaksanakan pemecahan masalah dengan memberikan masukan perbaikan atas kekurangan dan kelemahan yang terdapat di organisasi yang diaudit (Perangin - angin dan Ariyanto, 2017).

Bayangkara (2016) mengungkapkan bahwa dalam proses pelaksanaan audit atas fungsi sumber daya manusia dapat dibagi menjadi tiga kelompok sesuai dengan administrasi aset tetap pada umumnya, yakni perolehan, penggunaan, dan penghentian penggunaan, dimana perolehan yang dimaksud adalah proses dimana sumber daya manusia tersebut dapat direkrut menjadi bagian dari organisasi, dimana pada kelompok pertama ini dimulai kegiatan perencanaan kebutuhan SDM sampai dengan penempatan sumber daya manusi, kemudian kelompok kedua yakni penggunaan yang berarti proses pelatihan/pengembangan karyawan sampai pada penilaian kinerja, dan pada kelompok ketiga yakni penghentian penggunaan, dimana yang termasuk di dalamnya adalah pensiun, pengunduran diri, pemutusan hubungan kerja dan juga karyawan meninggal. Penelitian di Hotel X Seminyak ini dilakukan untuk mengidentifikasi peluang yang optimal dan juga memberikan rekomendasi bagi pihak manajemen untuk perbaikan operasi yang dijalankan.

Pengauditan dapat diartikan sebagai suatu proses sistematis untuk memeroleh dan mengevaluasi bukti yang berhubungan dengan asersi tentang tindakan-tindakan dan kejadian-kejadian ekonomi secara obyektif untuk menentukan tingkat kepatuhan asersi tersebut dengan kriteria yang telah 
ditetapkan dan mengkomunikasikan hasilnya kepada pihak-pihak yang berkepentingan (Jusup, 2014). Audit dapat dibagi menjadi 3 golongan, yakni: audit laporan keuangan, audit kepatuhan, dan audit operasional/manajemen Audit manajemen merupakan suatu evaluasi efisiensi dan efektivitas operasional organisasi (Nasution, 2016). Terdapat lima sumber utama yang dapat digunakan untuk menilai daya saing suatu organisasi yakni sumber keuangan, SDM, sumber daya intelektual, sumber daya organisasi, dan sumber daya fisik (Newbert, 2008).

Audit manajemen SDM merupakan bagian dari audit manajemen. Audit manajemen sumber daya manusia biasanya dilakukan pada fungsi-fungsi operasional dari manajemen SDM ataupun program-programnya seperti perencanaan SDM, rekrutmen, seleksi dan penempatan serta pelatihan dan pengembangan (Perangin-angin dan Ariyanto, 2017) (Maulana, 2014). Pendekatan utama yang digunakan sebagai acuan dalam kegiatan audit manajemen yakni menentukan ketaatan kepada peraturan dan hukum yang digunakan, mengukur antara kesesuaian program dengan tujuan organisasi dan juga dengan mengukur kinerja program sehinnga akan diketahui apakah program yang direncanakan tidak melanggar peraturan yang berlaku (Shiri, 2012). Audit SDM dapat dilakukan dengan menggunakan 5 tahap, yakni audit pendahuluan, review terhadap sistem pengendalian manajemen, audit lanjutan, penilaian efektivitas dan pelaporan, dan yang terakhir yakni tindak lanjut. Audit atas fungsi SDM di perusahaan dapat membantu manajer mengidentifikasikan penyimpangan antara kondisi aktual dengan kondisi yang diinginkan (Dismawati dan Suryono, 2013). Audit manajemen SDM dilaksanakan untuk mengembangkan kinerja 
karyawan dalam perusahaan. Peningkatan kinerja karyawan dapat dilihat sebagai sebuah keberhasilan perusahaan, dan faktor yang dapat berperan yakni proses dari pelaksanaan sasaran audit manajemen SDM, karena ketika manajemen SDM telah berjalan dengan tepat maka perusahaan dapat memperbaiki kinerja karyawan sesuai dengan kriteria perusahaan (Perangin-angin dan Ariyanto, 2017).

Audit SDM dilakukan untuk melihat apakah jumlah kuantitas dan juga kualitas dari sumber daya manusia yang dibutuhkan oleh organisasi perusahaan telah terpenuhi secara efektif dan juga efisien (Papina dan Aisyah, 2016). Audit SDM merupakan suatu alat kontrol manajemen yang penting dan merupakan suatu kebutuhan bagi organisasi bisnis pada era sekarang walaupun belum terdapatnya suatu keharusan yang memaksa untuk dilaksanakannya audit manajemen SDM (Kumari, 2017), (Saleem dan Akbar, 2015), (Burma, 2014). Mengingat bahwa sumber daya manusia meruapakan hal yang pada saat sekarang berperan penting dalam organisasi, audit manajemen digunakan untuk mengetahui apakah keefektifan dan keefisienan dari SDM tersebut telah berjalan sesuai dengan tujuan dan kriteria yang dibuat oleh perusahaan, maka audit sumber daya manusia menjadikan keseluruhan aktivitas SDM yang ada sebagai ruang lingkup audit (Hariyanto dan Widijoko, 2013) (Negi dan Chaubey, 2015). Pengelolaan SDM yang tepat dapat membantu organisasi untuk mendapatkan, mengembangkan dan mengevaluasi karyawan sesuai dengan kualifikasi yang dibutuhkan oleh perusahaan karena SDM mempunyai peran yang strategis yakni sebagai pemikir, perencana, dan pengendali aktivitas perusahaan dengan inovasi, bakat, tenaga dan kreativitas yang dimiliki oleh SDM untuk bersaing dan 
mwujudkan tujuan perusahaan (Giri, Julianto, dan Sujana, 2017), (Tan dan Nasurdin, 2011). Aktivitas SDM yang dimaksud yakni aktivitas yang dimulai dari proses perolehan SDM, Penggunaan SDM, dan kemudian Pemutusan Hubungan kerja dengan SDM tersebut.

Efektivitas merupakan hubungan antara keluaran dengan tujuan atau sasaran yang harus dicapai (Sumenge, 2013). Kegiatan operasional dikatakan efektif apabila proses kegiatan mencapai tujuan dan sasaran akhir kebijakan (spending wisely) (Novelya, Jantje, dan Sintje, 2016). Dalam ruang lingkup audit sumber daya manusia, efektivitas dapat ditekankan kepada tingkat pencapaian tujuan program ataupun kegiatan yang sudah ditetapkan, sehingga dapat dilihat hasil yang nyata dari kegiatan pengelolaan manajemen SDM oleh departemen SDM (Majerová, 2008). Efektivitas manajemen sumber daya manusia berkontribusi pada kesuksesan suatu organisasi(Jackson, Schuler, dan Jiang, 2014). Penelitian ini melakukan penilaian keefektifitasan dengan membandingkan pada kriteria yang ditentukan, dimana kriteria yang dimaksudkan adalah kriteria yang berupa tujuan perusahaan, peraturan karyawan beserta dengan Undang Undang ataupun Ketetapan Pemerintah yang mengatur tenaga kerja yang digunakan oleh management untuk mengatur SDM yang terdapat di dalam organisasi (Itika, 2013). Penggunaan audit sumber daya manusia memiliki banyak keuntungan, seperti bagi organisasi hasil audit SDM manusia dapat digunakan oleh manager dalam membuat suatu keputusan yang strategis yang tentunya akan dapat menarik bagi investor (Devi, 2015). Manajemen sumber daya yang efektif mengharuskan manajer untuk menemukan cara terbaik dalam 
mengkaryakan orang-orang untuk mencapai tujuan perusahaan dan meningkatkan kinerja organisasi karena manajemen SDM dapat meningkatkan efektivitas organisasinya, Untuk itu manajer diharapkan mampu untuk mencari berbagai cara untuk meningkatkan kepuasan kerja, komitmen, keterlibatan dalam kehidupan organisasi, kualitas lingkungan kerja dan efisiensi dan produktivitas karyawannya (Martini, 2017).

Penelitian ini akan menitikberatkan pada kegiatan aktivitas-aktivitas manajemen SDM seperti : perencanaan, rekrutmen, seleksi dan penempatan, pelatihan dan pengembangan SDM, perencanaan dan pengembangan karier, keselamatan dan kesehatan kerja, serta pemutusan hubungan kerja.

\section{METODE PENELITIAN}

Penelitian ini merupakan penelitian deskriptif kualitatif dengan pendekatan studi kasus. Penelitian ini merupakan penelitian tentang audit manajemen atas fungsi SDM di Hotel X Seminyak yang merupakan hotel berbintang lima yang berada di Seminyak, Bali.

Variabel dalam penelitian ini merupakan variabel tunggal yakni penerapan audit manajemen atas fungsi SDM. Audit manajemen atas fungsi SDM merupakan evaluasi secara menyeluruh terhadap tujuan, rencana dan program/aktivitas SDM dengan tujuan yakni memberikan rekomendasi perbaikan dalam pelaksanaan program kebijakan (Istanti, 2013) (Maharani dan Sari, 2014). Penelitian ini menggunakan ruang lingkup audit manajemen sebagai variabel dalam penelitian. Ruang lingkup audit yang dimaksud yakni aktivitas SDM, yakni aktivitas yang dimulai dari proses perolehan SDM mencakup proses 
perencanaan SDM, rekrutment, seleksi dan penempatan, dan juga orientasi dan penempatan. Proses penggunaan dan pengelolaan SDM mencakup pelatihan dan pengembangan karyawan, perencanaan dan pengembangan karir, penilaian kinerja, kompensasi dan balas jasa, keselamatan dan kesehatan kerja, dan kepuasan kerja karyawan. Proses pemutusan hubungan kerja yang merupakan bagian dari kegiatan manajemen SDM yang terdapat di dalam organisasi (Prasad dan Babu, N, 2017).

Data yang dipergunakan dalam penelitian ini digolongkan menjadi dua jenis yaitu data kualitatif dan data kuantitatif (Sugiyono, 2016). Data kualitatif yang terdapat pada penelitian ini adalah penyataan dan juga struktur organisasi yang diberikan oleh pihak yang di wawancara di Hotel X Seminyak. Dan data kuantitatif yang terdapat pada penelitian ini adalah daftar jumlah karyawan yang terdapat di Hotel X Seminyak. Sumber data dalam penilitian ini dibedakan menjadi dua berdasarkan cara memperoleh data tersebut menurut (Siregar, 2010) yakni data primer dalam penelitian ini berupa pernyataan dan jawaban yang diberikan oleh narasumber yang terdapat di Hotel X Seminyak. Dan data sekunder dalam penelitian ini meliputi data yang berisikan tentang daftar karyawan hotel, sejarah singkat hotel, dan juga struktur organisasi hotel X Seminyak.

Penelitian dengan menggunakan metode kualitatif ini menggunakan sampel dengan sifat purposive. Informan dalam penelitian yakni Informan Formal yang terdiri atas Manajer Human Resorces Department (HRD), dan juga Exceutive Manajer dan Informan Pendukung yakni karyawan yang telah bekerja di Hotel X 
Seminyak yang mengetahui tentang program dan pengelolaan SDM di Hotel X Seminyak.

Teknik pengumpulan data dalam penelitian ini yakni menggunakan teknik wawancara, observasi dan dokumentasi. Wawancara dilakukan dengan pihak Hotel X Seminyak yakni manajer SDM, manajer departemen dan beberapa karyawan Hotel X Seminyak. Obsevasi yang dilakukan meliputi obeservasi terhadap ruang lingkup audit atas fungsi SDM di lingkungan Hotel X Seminyak. Teknik dokumentasi yaitu pengumpulan data yang diperoleh dari catatan-catatan dan juga dokumen-dokumen yang terdapat di Hotel $\mathrm{X}$ Seminyak yang berhubungan dengan penelitian yang dilakukan.Instrumen dalam penelitian ini yakni program audit. Program audit merupakan rencana dan langkah kerja yang harus diikuti oleh peneliti dalam melaksanakan tugas audit sehingga audit dapat berjalan dengan lebih efektif dan efisien (Rochman, Andini, dan Oemar, 2016). Penggunaan program audit sebagai instrumen dalam penelitian membutuhkan seorang reviewer terhadap program audit yang dilaksanakan oleh peneliti. Adapun reviewer dalam penelitian ini yakni pembimbing peneliti. Reviewer berfungsi untuk melihat keabsahan dari data yang di peroleh peneliti dan kemudian membandingkan antara bukti yang dimiliki dengan penyataan yang terdapat di kertas kerja audit.

Teknik analisis data yang digunakan dalam penelitian ini adalah menggunakan metode analisis deskriptif kualitatif. Analisis deskriptif kualitatif adalah analisis data dengan cara mengumpulkan dan menjelaskan data non angka 
(kualitatif), kemudian membandingkan dengan teori yang bersangkutan untuk memperoleh kejelasan hasil yang akan dijadikan sebagai kesimpulan dan saran.

Langkah analisis data yakni menetapkan kriteria (criteria) yakni standar atau norma yang merupakan pedoman yang digunakan dalam beraktivitas dalam melaksanakan tanggung jawab dan wewenang. Kemudian mendeskripsikan kondisi (condition) yakni keadaan sebenarnya yang terjadi di dalam organisasi. Dilanjutkan dengan menemukan penyebab (causes) yakni semua tindakan yang dilaksanakan oleh pihak manajemen yang kemudian mengakibatkan perbedaan antara perencanaan dengan praktik di lapangan. Tahap selanjutnya yakni menentukan akibat yang merupakan dampak yang muncul karena terdapatnya penyebabyang merupakan perbandingan kriteria dengan penyebab. Tahap selanjutnya dilaksanakan pembahasan dan penilaian efektivitas yakni proses pemaparan lebih lanjut dengan membandingkan antara kondisi, kriteria, penyebab dan akibat. Penilaian efektivitas hasil temuan-temuan auditor kemudian akan di perjelas dan kemudian dilanjutkan dengan pemberian rekomendasi dari peneliti sehingga manajemen memungkinkan untuk melakukan perbaikan yang lebih baik.

Efektivitas setiap program audit dapat ditentukan dengan menggunakan kriteria yang ditetapkan yakni dengan membandingkan jumlah pernyataan yang disumpulkan "Ya" dibandingkan dengan jumlah total penyataan per program audit. Adapun rumus efektivitas dapat dirumuskan sebagai berikut :

Efektivitas Program $=\frac{\text { Jumlah Pernyataan dengan kesimpulan "Ya" }}{\text { Jumlah Total Pernyataan Program Audit }} \times 100 \%$

Dengan interpretasi nilai yakni : 
Tabel 1.

Interpretasi Nilai Efektivitas

\begin{tabular}{cl}
\hline \multicolumn{1}{c}{ Presentase } & \multicolumn{1}{c}{ Kriteria } \\
\hline $91-100 \%$ & Efektif \\
$81-90 \%$ & Cukup Efektif \\
$60-80 \%$ & Kurang Efektif \\
\hline er: Adaptasi dari Depdagri Kemendagri No.690.900.327
\end{tabular}

Setiap nilai yang diperoleh dari perhitungan akan menentukan tingkat efektivitas setiap program audit terhadap kegiatan manajemen sumber daya manusia yang terdapat di Hotel X Seminyak.

\section{HASIL DAN PEMBAHASAN}

Audit pendahuluan dilaksanakan dalam rangka untuk melakukan kegiatan audit yang lebih mendalam. Data diperoleh melalui wawancara dilaksanakan dengan informan yakni executive manager, manager SDM dan admin SDM, beserta dengan beberapa karyawan yang representatif. Kegiatan audit pendahuluan juga menekankan pada penetapan tujuan audit sementara yakni pada penilaiaan keefektifitasan pengelolaan manajamen sumber daya manusia di Hotel X Seminyak dengan menggunakan informasi-informasi yang diperoleh dari organisasi. Kegiatan perumusan tujuan audit sementara yang dilakukan oleh peneliti didasarkan pada tiga elemen, yakni kriteria (criteria), penyebab (cause), dan akibat (effect).

Kriteria yang digunakan peneliti dalam penelitian ini yakni peraturan karyawan, visi dan misi perusahaan, dan Undang-undang Nomor 13 Tahun 2003 tentang Ketenagakerjaan. Beberapa penyebab yang ditemukan oleh peneliti yakni telah dilaksanakannya program pelatihan yang meningkatkan tingkat jumlah pesanan/order produk, telah dilaksanakannya program kesehatan dan keseamatan kerja, pemberian jaminan kesehatan dan keselamatan kerja bagi karyawan tetap, 
belum dilaksanakan analisis lebih lanjut mengenai kebutuhan tenaga kerja di setiap departemen, dan terdapatnya kekurangan karyawan pada saat tertentu di departemen produksi. Sedangkan akibat yang ditemukan oleh peneliti yakni peningkatan pesanan/order kemudian mengakibatkan karyawan khusunya bagian produksi harus bekerja lembur, pemberian layanan jaminan kesehatan terbatas pada karyawan tetap saja, outlet bisnis yang mengalami kekosongan mengakibatkan pelayana yang diberikan kepada customer menjadi kurang maksimal, penggunaan tenaga kerja yang berasal dari tenaga kerja siswa dan mahasiswa yang training mengakibatkan pelayan kurang maksimal.

Kegiatan review dan pengujian pengendalian ini dilaksanakan dengan melaksanakan penelaahan kembali terhadap bukti-bukti untuk menjadi sebuah temuan audit. Pengendalian atas fungsi sumber SDM telah dilakukan dengan cara melakukan sosialisasi tujuan termasuk juga visi dan misi perusahaan kepada karyawan. Perhatian manajemen SDM juga meliputi terhadap kualitas dan juga kuantitas SDM yang terdapat di organisasi. Pemenuhan kebutuhan SDM di dalam organisasi juga telah diusahakan secara dengan maksimal, walaupun masih terdapatnya kelemahan dimana dari pengamatan yang dilakukan oleh peneliti menemukan bahwa beberapa unit dan bagian departemen yang terdapat di dalam organisasi masih membutuhkan tambahan karyawan. Pelaksanaan kegiatan manajemen SDM di dalam organisasi ini juga telah dilaksanakan sesuai dengan kebijakan yang terdapat di dalam organisasi. 
Audit lanjutan merupakan suau proses lanjutan dari kegiatan audit, proses ini peneliti mengelompokkan temuan ke dalam kelompok kondisi, kriteria, penyebab dan akibat.

Program perencanaan SDM yang terdapat di organisasi telah mematuhi peraturan Undang-Undang No 13 Tahun 2003 tentang Ketenagakerjaan Bab IV pasal 7-8, dimana hal ini dapat dilihat dari terdapatnya peraturan-peraturan yang mengatur tenaga kerja dan tertulis pada perjanjian kerja antara perusahaan dengan pekerja dan juga terdapat pada profil dari organisasi. Walaupun kegiatan perencanaan yang terdapat di dalam organisasi masih berupa perencanaan tenaga kerja untuk jangka waktu yang relatif pendek. Lihat pada Tabel 2, proses pengelompokan audit lanjutan perencanaan SDM.

Perhitungan efektivitas program :

$$
\text { Efektivitas program }=\frac{5}{7} \times 100 \%=71,43 \%
$$

Efektivitas program Perencanaan SDM dengan nilai 71,43\% dapat digolongkan pada kriteria yang kurang efektif. Hal ini disebabkan karena belum terdapatnya suatu standar khusus yang mengatur tentang perencanaan sumber daya manusia di dalam organisasi. Pemenuhan kebutuhan akan sumber daya manusia yang dilaksanakan dengan metode reaktif menyebabkan suatu waktu pemenuhan kebutuhan SDM tidak dapat diepenuhi secara tepat. 
ISSN: 2302-8556

E-Jurnal Akuntansi Universitas Udayana

Vol.25.2.November (2018): 1390-1417

Tabel 2.

Pengelompokan Program Audit Perencanaan SDM

\begin{tabular}{llll}
\hline & \multicolumn{2}{c}{ Kondisi } & \multicolumn{1}{c}{ Kriteria } \\
\hline Perencanaan & SDM belum memiliki & a. & Undang-undang No.13 Tahun 2003 \\
standar/kriteria yang ditetapkan. Pemenuhan & & tentang Ketenagakerjaan Bab IV pasal 7- \\
kebutuhan atas SDM manusia didasarkan atas & & 8. \\
permintaan dari kepala departemen yang & b. Tidak terdapatnya kriteria/standar khusus \\
membutuhkan, sehingga dapat diketahui bahawa & & $\begin{array}{l}\text { yang mengatur tentang perencanaan } \\
\text { analisis kebutuhan SDM hanya kebutuhan jangka }\end{array}$ & sumber daya manusia
\end{tabular}

\begin{tabular}{l}
\hline Penyebab \\
\hline Perusahaan tidak memiliki kriteria/standar khusus \\
yang mengatur tentang perencanaan SDM. \\
Perencanaan sumber daya manusia yang \\
didasrkan atas kebutuhan pada saat sekarang. \\
Sehingga pemenuhan kebutuhan karyawan hanya \\
didasarkan pada permohonan permintaan \\
tambahan karyawan yang dibuat oleh kepala \\
departmen. Pertimbangan penambahan tenaga \\
kerja yang juga didasarkan atas musim liburan \\
yang terjadi pada waktu tertentu (high and low \\
season).
\end{tabular}

Akibat
Belum terdapatanya kriteria khusus yang mengatur tentang perencanaan SDM di dalam organisasi menyebabkan pemenuhan kebutuhan SDM di dalam perusahaan baik itu kuantitas maupun kualitas belum dapat dipenuhi pada waktu yang tepat. Kekurangan sumber daya manusia pada waktu-waktu tertentu seperti kegiatan event yang dilaksanakan di dalam organisasi mengakibatkan sumber daya manusia yang terdapat di dalam organisasi harus bekerja ekstra/lembur.

Sumber: Data diolah, 2018

Program rekrutmen yang terdapat di organisasi telah mematuhi peraturan Undang-undang No.13 Tahun 2003 tentang Ketenagakerjaan Bab III pasal 5-6. Hal ini dapat dilihat dari kegiatan rekrutmen yang dilaksanakan oleh manajemen sumber daya manusia telah memberikan kesempatan yang sama dan tanpa diskriminasi bagi para pencari kerja untuk melamar pekerjaan di dalam organisasi. Peraturan dan kualifikasi yang jelas dan juga dengan penggunaan media berupa internet telah memberikan kesempatan yang luas untuk melamar pekerjaan bagi para pencari kerja. Lihat pada Tabel 3, proses pengelompokan audit lanjutan rekrutmen SDM.

Perhitungan efektivitas program :

$$
\text { Efektivitas program }=\frac{4}{4} \times 100 \%=100 \%
$$

Efektivitas program rekrutmen SDM dengan nilai 100\% dapat digolongkan pada kriteria yang efektif. Hal ini menunjukkan program rekrutmen yang dilaksanakan 
telah berjalan dengan baik. Penggunaan media online merupakan salah satu cara untuk mendapatkan tenaga kerja terbaik.

\section{Tabel 3.}

Pengelompokan Program Audit Rekrutment SDM

\begin{tabular}{|c|c|}
\hline Kondisi & Kriteria \\
\hline Proses rekrutmen yang dilaksanakan berdasarkan analisis & a. Undang-undang No.13 Tahun \\
\hline kebutuhan oleh HRD dan kepala bagian. Kegiatan rekrutmen & tentang \\
\hline $\begin{array}{l}\text { dilaksanakan dengan membagikan informasi lowongan kerja } \\
\text { di website pasar tenaga kerja seperti HRMMA Bali dengan }\end{array}$ & $\begin{array}{l}\text { Ketenagakerjaan } \quad \text { Bab III } \\
\text { pasal 5-6. }\end{array}$ \\
\hline
\end{tabular}
mencantumkan jenis lowongan pekerjaan yang tersedia dan juga kualifikasi/persyaratan yang harus dimiliki oleh pelamar kerja.

b. Tidak ada kriteria khusus yang mengatur tentang rekrutmen SDM

\begin{tabular}{|c|c|}
\hline Penyebab & Akibat \\
\hline $\begin{array}{l}\text { Proses rekrutmen dilaksanakan oleh bagian SDM di Hotel X } \\
\text { Seminyak sesuai dengan kebutuhan dari departemen yang } \\
\text { bersangkutan, penggunaan media online telah memberikan } \\
\text { peluang yang sama bagi para pencari kerja untuk } \\
\text { mengajukan lamarannya ke Hotel X Seminyak selama ia } \\
\text { telah memiliki kualifikasi yang ditetapkan oleh perusahaan. }\end{array}$ & $\begin{array}{l}\text { Perusahaan telah mampu untuk } \\
\text { mendapatkan tenaga kerja yang } \\
\text { paling tepat sesuai dengan } \\
\text { kualifikasi yang mereka terapkan } \\
\text { dalam lowongan pekerjaan, } \\
\text { disamping itu dengan penggunaan } \\
\text { media online/website jumlah } \\
\text { pelamar tenaga kerja yang melamar } \\
\text { tidak terbatas. }\end{array}$ \\
\hline
\end{tabular}

Sumber: Data diolah, 2018.

Program seleksi dan penempatan yang terdapat di organisasi telah mematuhi peraturan yang berlaku yakni Undang-undang No.13 Tahun 2003 tentang Ketenagakerjaan Bab IV pasal 31-36. Termasuk juga telah mematuhi Perjanjian Kerja yang dibuat oleh perusahaan. Hal ini dapat dilihat dari kegiatan penempatan tenaga kerja yang didasarkan dengan asas terbuka, bebas, obyektif serta adil, dan tanpa adanya diskriminasi terhadap calon tenaga kerja. Perjanjian Kerja yang telah memaparkan secara jelas mengenai wewenang dan jabatan dari seorang tenaga kerja merupakan salah satu bukti bahwa manajemen telah berupaya untuk mematuhi peraturan yang berlaku. Lihat pada Tabel 4, proses pengelompokan audit lanjutan seleksi dan penempatan SDM. 
ISSN: 2302-8556

E-Jurnal Akuntansi Universitas Udayana Vol.25.2.November (2018): 1390-1417

Tabel 4.

Pengelompokan Program Audit Seleksi dan Penempatan SDM

\begin{tabular}{|c|c|}
\hline Kondisi & Kriteria \\
\hline $\begin{array}{l}\text { Kegiatan seleksi dilakukan dengan melakukan } \\
\text { pengecekan berkas yang dimiliki oleh pelamar kerja. } \\
\text { Kemudian dilanjutkan dengan wawancara dan juga } \\
\text { kemudian trial (percobaan), pada tahap ini kepala } \\
\text { departemen akan menggali informasi latar belakang dan } \\
\text { juga informasi lainnya yang dibutuhkan oleh kepala } \\
\text { departemen yang menyangkut dengan proses seleksi. } \\
\text { Ketika phak SDM dan kepala departemen sepakat untuk } \\
\text { menerima calon teanga kerja maka tahap selanjutnya } \\
\text { adalah penempatan. Pada tahap ini penempatan akan } \\
\text { dilaksanakan berdasarkan permintaan dari kepala } \\
\text { departemen. }\end{array}$ & $\begin{array}{l}\text { a. Undang-undang No. } 13 \text { Tahun } \\
2003 \text { tentang Ketenagakerjaan, } \\
\text { Bab VI pasal 31-36. } \\
\text { b. Perjanjian kerja pada lembar ke-2 } \\
\text { bagian pengecekan kesehatan } \\
\text { sebelum. } \\
\text { c. Pembuka bagian Perjanjian Kerja }\end{array}$ \\
\hline $\begin{array}{l}\text { Penyebab } \\
\end{array}$ & Akibat \\
\hline $\begin{array}{l}\text { Penempatan pekerja yang didasarkan atas penyeleksian } \\
\text { yang dilaksanakan oleh kepala departemen } \\
\text { memudahkan dalam proses penempatannya, sehingga } \\
\text { posisi yang dianggap oleh kepala departemen paling } \\
\text { membutuhkan tambahan pekerjaan dapat dipenuhi. }\end{array}$ & $\begin{array}{l}\text { Pekerja yang diseleksi dan } \\
\text { ditempatkan dapat bekerja sesuai } \\
\text { dengan hasil dari seleksi yang } \\
\text { dilakukan oleh pihak SDM dan juga } \\
\text { kepala departemen menyebabkan } \\
\text { bagian yang membutuhkan tambahan } \\
\text { karyawan dapat memenuhi karyawan } \\
\text { sesuai dengan kebutuhannya. }\end{array}$ \\
\hline
\end{tabular}

Sumber: Data diolah, 2018.

Perhitungan efektivitas program :

$$
\text { Efektivitas program }=\frac{6}{7} \times 100 \%=85,71 \%
$$

Efektivitas program seleksi dan penempatan SDM dengan nilai 85,71\% dapat digolongkan pada kriteria cukup efektif. Kegiatan seleksi yang telah dijalankan dengan baik oleh manajemen masih belum sejalan dengan kegiatan penempatan SDM yang masih terdapat masalah, masalah tersebut yakni masih terdapatnya beberapa bagian departemen yang belum memenuhi jumlah karyawan dan terdapatnya departemen yang menggantungkan tanggung jawab kepada mahasiswa training, dan juga masih belum dikomunikasikannya keluhan kepada pihak kepala departemen. Hal ini dinilai kurang efektif, karena dapat menimbulkan kemungkinan - kemungkinan tindakan penyelewengan yang tidak diinginkan di dalam organisasi. 
Program pelatihan dan pengembangan SDM telah dibuat dan dilaksanakan sesuai dengan Undang-undang No.13 Tahun 2013 tentang Ketenagakerjaan Bab V pasal 9-30. Hal ini dibuktikan dengan telah dilaksanakannya kegiatan pelatihan di dalam organisasi, dan pelatihan yang dilaksanakan juga tidak terbatas pada tenaga kerja di dalam organisasi tetapi juga dengan telah diberikannya kesempatan kepada siswa dan mahasiswa untuk berlatih di dalam organisasi dalam kegiatan yang disebut dengan pemagangan (training). Lihat pada Tabel 5, proses pengelompokan audit lanjutan pelatihan dan pengembangan SDM.

Tabel 5.

Pengelompokan Program Pelatihan dan Pengembangan SDM

\begin{tabular}{|c|c|}
\hline Kondisi & Kriteria \\
\hline $\begin{array}{l}\text { Pelatihan-pelatihan yang dilaksanakan di Hotel X } \\
\text { Seminyak hampir dilaksanakan di seluruh departemen. } \\
\text { Pelatihan mengenai keselamatan kerja, pelatihan } \\
\text { produksi dan pelatihan lainnya. Pelatihan ini telah } \\
\text { mampu untuk meningkatkan keahlian karyawan. } \\
\text { Program pelatihan juga memberikan kesempatan yang } \\
\text { dibuka bagi siswa dan juga mahasiswa yang } \\
\text { melaksanakan program magang/training. }\end{array}$ & $\begin{array}{l}\text { a. Undang-undang No. } 13 \text { Tahun } 2013 \\
\text { tentang Ketenagakerjaan Bab V } \\
\text { pasal 9-30. }\end{array}$ \\
\hline Penyebab & Akibat \\
\hline $\begin{array}{l}\text { Kegiatan pelatihan yang dilaksanakan telah berjalan } \\
\text { dengan baik, dimana keseluruhan karyawan telah } \\
\text { diberikan kesempatan untuk mengikuti program } \\
\text { pelatihan. Keberhasilan pelatihan yang dirasakan oleh } \\
\text { pekerja seperti di bidang produksi kemudian } \\
\text { mengakibatkan peningkatan pesanan. Pemanfaatan } \\
\text { tenaga yang bersumber dari mahasiswa/siswa training } \\
\text { kemudian dapat membantu kegiatan operasional. }\end{array}$ & $\begin{array}{l}\text { Kegiatan pelatihan yang telah } \\
\text { dilaksanakan di hampir keseluruhan } \\
\text { lapisan pekerja telah mampu } \\
\text { meningkatkan keahlian pekerja. Hal ini } \\
\text { kemudian berdampak baik bagi } \\
\text { kegiatan operasional perusahaan. } \\
\text { Disamping itu tambahan mahasiswa } \\
\text { magang telah mampu untuk membantu } \\
\text { kegiatan operasional organisasi. }\end{array}$ \\
\hline
\end{tabular}

Sumber: Data diolah, 2018

Perhitungan efektivitas program :

$$
\text { Efektivitas program }=\frac{6}{6} \times 100 \%=100 \%
$$

Efektivitas program pelatihan dan pengembangan SDM dengan nilai 100\% dapat digolongkan pada kriteria efektif. Pelatihan dan pengembangan karyawan yang berada di organisasi dilaksanakan berdasarkan analsis kebutuhan karyawan dan 
organisasi dan telah dapat meningkatkan kinerja karyawan yang kemudian berpengaruh pada peningkatkan jumlah order dari pelanggan..

Perencanaan dan pengemangan karier yang berada di organisasi telah mematuhi Undang-undang No.13 Tahun 2003 tentang Ketenagakerjaan, Bab VII pasal 39-41, dan juga telah mematuhi perjanjian kerja antara perusahaan dengan pekerja. Hal ini dapat dilihat dari telah dilaksanakannya kegiatan pengembangan karier di dalam organisasi hal ini kemudian akan meningkatkan perluasan kesempatan kerja dan juga dengan penciptaan kegaitan yang produktif dan berkelanjutan. Disamping itu, kegiatan perencanaan dan pengembangan karier dilaksanakan oleh organisasi tidak terbatas pada pekerja dengan status tetap tetapi juga dengan pekerja dengan status magang (training) dan juga karyawan kontrak. Lihat pada Tabel 6, proses pengelompokan audit lanjutan perencanaan dan pengembangan karier SDM.

Perhitungan efektivitas program :

$$
\text { Efektivitas program }=\frac{5}{5} \times 100 \%=100 \%
$$

Efektivitas program perencanaan dan pengembangan karier SDM dengan nilai $100 \%$ dapat digolongkan pada kriteria efektif. Program perencanaan dan pengembangan karier telah dilaksanakan kepada seluruh lapisan pekerja di dalam organisasi hotel. Pengangkatan mahasiswa training menjadi daily worker/staf, pengangkatan daily worker menjadi staff tetap dan juga promosi karyawan tetap ke jabatan yang lebih tinggi telah dilaksanakan di dalam organisasi. 
Tabel 6.

Pengelompokan Program Audit Perencanaan dan Pengembangan Karier SDM

\begin{tabular}{|c|c|}
\hline Kondisi & Kriteria \\
\hline $\begin{array}{l}\text { Perencanaan dan pengembangan karier yang } \\
\text { dilaksanakan oleh Hotel X Seminyak merupakan suatu } \\
\text { upaya untuk meningkatkan prestasi kerja karyawan. } \\
\text { Pengambangan karier karyawan ini tidak terbatas pada } \\
\text { karyawan tetap saja, tetapi keseluruhan karyawan yang } \\
\text { berada di organisasi. Pemberian kesempatan bagi } \\
\text { karyawan yang berprestasi dan menunjukkan kinerja } \\
\text { yang baik memungkinkan karyawan tersebut untuk } \\
\text { memperoleh status dan jabatan yang lebih tinggi. } \\
\text { Seperti dari mahasiswa magang yang kemudian } \\
\text { diangkat menjadi staf, pekerja DW menjadi staf tetap, } \\
\text { dan juga promosi jabatan lainnya. }\end{array}$ & $\begin{array}{l}\text { a.Undang-undang No. } 13 \text { Tahun } 2003 \\
\text { tentang Ketenagakerjaan, Bab VII pasal } \\
\text { 39-41. } \\
\text { b. Perjanjian Kerja di halaman } 4 \text { bagian } \\
\text { Penilaian dan Evaluasi. }\end{array}$ \\
\hline Penyebab & Akibat \\
\hline $\begin{array}{l}\text { Pemberian kesempatan bagi setiap pekerja untuk } \\
\text { memperoleh status dan jabatan yang lebih tinggi } \\
\text { meningkatkan semangat karyawan dalam bekerja. } \\
\text { Bentuk penghargaan dan prestasi kerja yang dibuat oleh } \\
\text { pekerja dihargai oleh organisasi dengan } \\
\text { dilaksanakannya program promosi. }\end{array}$ & $\begin{array}{l}\text { Dengan semangat tersebut pekerjaan } \\
\text { yang terdapat di wilayah hotel dapat } \\
\text { berjalan dengan baik dan terkordinasi } \\
\text { dengan baik dan juga terjadinya } \\
\text { persaingan yang sehat di antara } \\
\text { karyawan yang terdapat di hotel. }\end{array}$ \\
\hline
\end{tabular}
Sumber: Data diolah, 2018.

Program kesehatan dan keselamatan kerja yang terdapat di organisasi telah mematuhi Undang-undang No.13 Tahun 2003 tentang Ketenagakerjaan Bab X pasal 86-87, termasuk juga telah mematuhi perjanjian kerja. Bentuk pemberian jaminan kesehatan kerja kepada karyawan dengan kerja sama dengan penyedia layanan jaminan kesehatan seperti BPJS Kesehatan merupakan bentuk kepedulian perusahaan kepada pekerja sesuai dengan ketetapan undang-undang yang menyaratkan bahwa manajemen harus menerapkan sistem kesehatan dan keselamatan kerja yang terintegrasi dengan sistem manajemen. Lihat pada Tabel 7, proses pengelompokan audit lanjutan keselamatan dan kesehatan SDM.

$$
\text { Efektivitas program }=\frac{9}{10} \times 100 \%=90 \%
$$

Efektivitas program keselamatan dan kesehatan kerja SDM dengan nilai $90 \%$ dapat digolongkan pada kriteria cukup efektif. Program yang dijalankan oleh 
ISSN: 2302-8556

E-Jurnal Akuntansi Universitas Udayana Vol.25.2.November (2018): 1390-1417

perusahaan dalam kegiatan prosesnya masih terdapat pelanggaran oleh pekerja di dalam organisasi. Kurangnya kesadaran pekerja akan pentingnya kesehatan keselamatan kerja merupakan suatu bentuk kurangnya pengetahuan akan pentingnya keslamatan kerja, sehingga program ini masih digolongkan pada kriteria cukup efektif akibat dari masih terdapatnya pelanggaran yang dilakukan oleh pekerja. Akibatnya program ini masih perlu untuk diperbaiki sehingga akan menjadi efektif.

Tabel 7.

Pengelompokan Program Audit Keselamatan dan Kesehatan Kerja SDM Kondisi Kriteria

Program keseamatan di Hotel X Seminyak telah dijalankan dengan baik. Pemberian asuransi kesehatan dan keselamatan kerja merupakan salah satu program yang terdapat di hotel ini, disamping itu perlengkapan kebutuhan perlindungan karyawan juga telah dilengkapi oleh manajemen. Sistem komunikasi bahaya yang telah terintergrasi antar satu departemen ke departemen lainnya sangat mendukung program ini, penyediaan kotak P3K, kilik in house, dan juga perlengkapan kesehatan lainnya telah dipasang hampir diseruh bagian yang dianggap perlu.

\begin{tabular}{|c|c|}
\hline Penyebab & Akibat \\
\hline $\begin{array}{l}\text { Penyediaan perlengkapan keselamatan dan } \\
\text { kesehatan kerja yang telah dipenuhi oleh } \\
\text { manajemen bertujuan untuk melindungi karyawan } \\
\text { dari ancaman bahaya, berfungsi untuk } \\
\text { meningkatkan kualitas kesehatan dan keselamatan } \\
\text { kerja, sehingga karyawan merasa aman dalam } \\
\text { melaksanakan kegiatan yang mereka laksanakan di } \\
\text { wilayah hotel. Tetapi masih terdapatnya } \\
\text { pelanggaran berupa karyawan yang tidak } \\
\text { menggunakan standar pakaian sesuai dengan } \\
\text { prosedur teapi belum ditindak oleh manajamen. }\end{array}$ & $\begin{array}{l}\text { Kelengkapan yang telah diberikan oleh } \\
\text { pihak manajemen masih sering dilanggar } \\
\text { oleh karyawan yang tidak menggunaan } \\
\text { perlengkapan standar ketika bekerja. } \\
\text { Peningkatan ancaman bahaya yang } \\
\text { sesuungguhnya telah diusahakan oleh } \\
\text { manajemen masih dilanggar oleh karyawan } \\
\text { yang berarti masih kurangnya pemahaman } \\
\text { karyawan akan ancaman bahaya kerja, } \\
\text { padahal hal tersebut dapat merugikan } \\
\text { karyawan, perusahaan dan bahkan } \\
\text { pelanggan hotel. }\end{array}$ \\
\hline
\end{tabular}
Sumber: Data diolah, 2018.

a. Undang No.13 Tahun 2003 tentang

Ketenagakerjaan Bab X pasal 86-87.

b. Perjanjian kerja halaman 2 bagian Program BPJS dan Pengobatan.

Program pemutusan hubungan kerja yang terdapat di organisasi telah mematuhi Undang-undang No.13 tahun 2003 tentang Ketenagakerjaan Bab XII pasal 150-172, dan juga telah sejalan dengan peraturan yang terdapat di dalam 
organisasi tertulis pada perjanjian kerja perusahaan. Lihat pada Tabel 8, proses pengelompokan audit lanjutan pemutusan hubungan kerja.

Perhitungan efektivitas program:

$$
\text { Efektivitas program }=\frac{3}{3} \times 100 \%=100 \%
$$

Efektivitas program pemutusan hubungan kerja dengan nilai $100 \%$ dapat digolongkan pada kriteria efektif. Hal ini dapat dilihat dari perusahaan telah membuat tata cara dan peraturan mengenai pemutusan hubungan kerja sesuai dengan perjanjian kerja dan juga telah mensosialisasikannya kepada karyawan.

Tabel 8.

Pengelompokan Program Audit Pemutusan Hubungan Kerja

Kondisi Kriteria

Program pemutusan hubungan kerja akibat dari kelalaian dan pelanggaran fatal yang diperbuat oleh karyawan merupakan hal mutlak yang harus dilaksanakan. Disamping itu pemutusan hubungan kerja akibat dari keinginan karyawan juga dilaksanakan sesuai dengan prosedur yang dimiliki oleh perusahaan yang tercantum dalam perjanjian kerja.

a. Undang-undang No.13 Tahun 2003 tentang Ketenagakerjaan Bab XII pasal 150-172.

b. Perjanjian kerja di halaman 4 bagian Pemutusan Hubungan Kerja.

\begin{tabular}{lll}
\hline & Penyebab & Akibat \\
\hline Kebijakan mengenai PHK telah dicantumkan dalam Proses PHK telah dapat berjalan \\
perjanjian kerja. Proses PHK dilakukan ketika karyawan sesuai dengan prosedur yang \\
tidak mencapai prestasi kerja yang memuaskan dengan terdapat di perusahaan. Karyawan \\
pembinaan dan peringatan paling banyak 3 (tiga) kali, dan juga telah diberikan pengetahuan \\
PHK juga dapat dilakukan secara langsung tanpa yang cukup mengenai hal-hal yang \\
pemberitahuan jika terjadi pelanggaran berat terhadap & dapat menyebabkan seorang \\
Peraturan Undang-Undang Republik Indonesia. & karyawan di putuskan hubungan \\
& kerjanya dengan perusahaan.
\end{tabular}

Sumber: Data diolah, 2018.

Penelitian yang dilaksanakan di Hotel X Seminyak ini terdapat beberapa keterbatasan dalam meneliti seperti keterbatasan waktu. Terbatasnya waktu penelitian yang dilaksanakan oleh peneliti di dalam organisasi yakni Mei-Juni 2018, sehingga hasil penelitian keefektifitasan sumber daya manusia di Hotel X Seminyak ini tidak dapat dijadikan sebagai acuan jangka panjang. Beserta keterbatasan akses data dimana sebagian data bersifat rahasia bagi perusahaan. 
Oleh karena itu, perusahaan tidak dapat memberikan data-data yang dapat menunjang penelitian ini untuk menjadi lebih lengkap seperti hasil penilaian kerja karyawan, rekap gaji dan absensi karyawan, dan sebagainya yang bersifat rahasia.

\section{SIMPULAN}

Simpulan yang dapat diambil yakni program perencanaan sumber daya manusia digolongkan pada kriteria kurang efektif, penyebab kurang efektif tersebut yakni belum terdapatnya standar yang mengatur sumber daya manusia di dalam organisasi. Program rekrutmen telah berjalan dengan efektif, pemaparan kualifikasi yang harus dimiliki oleh pelamar kerja untuk dapat mengajukan diri secara jelas merupakan hal bijak untuk mendapatkan pekerja yang paling tepat untuk direkrut. Program seleksi dan penempatan digolongkan sebagai kriteria cukup efektif, penyebab digolongkannya program tersebut pada kriteria cukup efektif yakni karena masih terdapatnya kelemahan dalam program penempatan karyawan dimana terdapatnya beberapa bagian dari departemen yang tugas dan pekerjaannya masih dirangkap dan dikerjakan oleh pekerja yang belum terlatih.

Program pelatihan dan pengembangan yang dilaksanakan telah berjalan dengan efektif, pelatihan yang telah dilaksanakan baik itu untuk keseluruhan pekerja maupun pelatihan di departemen khusus yang dilaksanakan telah sesuai dengan kebutuhan karyawan. Program perencanaan dan pengembangan karier SDM telah berjalan dengan efektif, pelaksanaan perencanaan dan pengembangan karier yang dilaksanakan bagi seluruh lapisan pekerja telah mampu diterapkan dan berjalan dengan baik. Program kesehatan dan keselamatan kerja digolongkan pada kriteria cukup efektif, hal ini disebabkan oleh kepedulian karyawan yang rendah 
terhadap perlindungan diri untuk mencegah terjadinya kecelakaan kerja masih dihiraukan oleh pekerja. Program pemutusan hubungan kerja yang berlaku di telah berjalan dengan efektif. Peraturan yang jelas yang telah disosialisasikan kepada seluruh karyawan yang bekerja di Hotel X Seminyak membuat karyawan dapat memahami dengan jelas mengenai prosedur PHK.

Saran yang dapat diberikan oleh peneliti bagi Hotel X Seminyak yakni manajemen kiranya membuat perencanaan sumber daya manusia yang terdokumentasi yang jelas, standar dan kriteria yang jelas mengenai kualitas dan juga kuantitas sumber daya manusia di setiap bagian departemen akan mempermudah manajemen untuk mengatur operasional organisasinya. Direkrutnya tambahan pekerja yang memiliki kualifikasi terbaik di departemen yang membutuhkan tambahan pekerja seperti di departemen produksi dan juga unit usaha, penambahan tenaga kerja baru yang telah terlatih akan menghindari penurunan kualitas yang diberikan kepada pelanggan. Sistem komunikasi yang lebih terbuka kepada seluruh karyawan, sistem komunikasi terbuka dapat memberikan kesempatan oleh setiap karyawan dalam menyampaikan keluhan kepada pemilik kebijakan, sehingga pemilik kebijakan akan dapat dengan lebih mudah menetapkan kebijakan. Dilakukannya proses pemisahan tugas yang lebih jelas, sehingga kemungkinan-kemungkian yang tidak diinginkan dapat diminimalisir.

Pelaksanaan sosialisasi yang lebih intensif kepada karyawan-karyawan tentang pentingnya kesehatan dan keselamatan kerja sehingga pelanggaran dapat diminimalisir dengan pengetahuan dan sosialisasi mengenai pentingnya kesehatan 
dan perlindungan diri bagi pekerja dan organisasi. Sedangkan saran bagi peneliti selanjutnya, kiranya peneliti menambahkan program audit SDM lainnya, seperti program audit kompensasi SDM dan program audit lainnya yang berhubungan dengan audit manajemen sumber daya manusia.

\section{REFERENSI}

Bayangkara, I. B. K. (2016). Audit Manajemen: Prosedur dan Implementasi. Jakarta: Penerbit Salemba Empat.

Burma, Z. A. (2014). Human Resource Management and Its Importance For Today's Organizations. International Journal of Education and Social Science, 1(2), 85-94.

Devi, U. N. (2015). Human Resource Audit and It's Implication on Organizazional Efficiency: An Exploratory Study. International Journal of Organizational Behaviour \& Management Perspectives - Pezzottaite Journals., 4(2), 1677-1681.

Dismawati, L. R., \& Suryono, B. (2013). Penerapan Audit Manajemen Sumber Daya Manusia Untuk Menilai Kinerja Pada Bank Maspion. Jurnal Ilmu \& Riset Akuntansi, 2(11), 1-17.

Giri, W. A. W., Julianto, I. P., \& Sujana, E. (2017). Pengaruh Efektvitias Sumber Daya Manusia, Modal Kerja dan Efektivitas Biaya Operasional Terhadap Sisa Hasil Usaha BUMDes ( Studi Empiris pada BUMDes di Kecamatan Kubutambahan ). E-Journal S1 Ak Universitas Pendidikan Ganesha, 8(2), 112.

Hariyanto, R., \& Widijoko, G. (2013). Audit Manajemen Sebagai Sarana Untuk Menilai Efektivitas Fungsi Sumber Daya Manusia (Studi Kasus pada PT Bank Rakyat Indonesia Cabang Pasuruan). Jurnal Ilmiah Mahasiswa FEB Universitas Brawijaya, 2(1).

Istanti, E. (2013). Audit Manajemen dan Penilaian Kinerja Pemasaran. Jurnal WIGA, 3(1), 35-41.

Itika, J. S. (2013). Fundamentals of human resources management: Human Resource Policies. Africal Public Administration and Management, 2(3), 4362 . 
Sony Ricardo Sembiring dan Ketut Budiartha. Efektivitas...

Jackson, S. E., Schuler, R. S., \& Jiang, K. (2014). Strategic HRM: a review and framework. Journal of Academy Management Annuals, 8(1), 1-56.

Jusup, A. H. (2014). Auditing Pengauditan Berbasis ISA (2nd ed.). Yogyakarta: STIE YKPN.

Kumari, S. (2017). HR Audit: An Emerging Tool of Human Resource Management. International Journal of Business Administratition and Management, 7(1), 216-228.

Mahajan, R. K. (2015). Changing Role Of HRM In The Era Of Globalisation. International Journal of Organizational Behaviour \& Management Perspectives - Pezzottaite Journals., 4(2), 1690-1692.

Maharani, L. G. D. P., \& Sari, M. M. R. (2014). Persepsi Karyawan Atas Audit Manajemen Sumber Daya Manusia Pada Kinerja Karyawan. E-Jurnal Akuntansi Universitas Udayana, 8(3), 538-553.

Majerová, R. (2008). Measuring of the Human Resource Effectiveness. Journal of Human Resource Management \& Ergonomics, 2(1).

Martini, N. P. R. (2017). Pengaruh Penempatan Sumber Daya Manusia pada Kinerja Karyawan di Pemerintah Kabupaten Badung. Jurnal KRISNA: Kumpulan Riset Akuntansi, 9(1), 70-79.

Maulana, Y. (2014). Audit Manajemen. Jurnal Dan Majalah Bisnis Dan Iptek STIE Pasundan Bandung, 7(2), 58-69.

Nasution, Y. P. S. (2016). Audit Manajemen Untuk Menilai Kinerja Fungsi SDM (Studi pada Fungsi Rekrutmen-Seleksi-Orientasi, Pelatihan dan Pengembangan, Penilaian Prestasi Kerja, dan Pemutusan Hubungan Kerja PT. XYZ Indonesia - Medan). Jurnal Administrasi Bisnis (JAB), 40(2), 6571.

Negi, A., \& Chaubey, D. S. (2015). Human Resources Audit System for Evaluating Employees Performance. International Journal of Research in Economics and Social Sciences, 5(8).

Newbert, S. L. (2008). Value, Rareness, Competitive Advantage, and Performance: A Conceptual-Level Empirical Investigation of the ResourceBased View of the Firm. Strategic Management Journal, 29(7), 745-768. https://doi.org/10.1002/smj.686

Nickels, W. G. M., James M., M., \& Susan, M. (2010). Pengantar Bisnis (8th ed.). Jakarta: Penerbit Salemba Empat. 
Novelya, S., Jantje, T., \& Sintje, R. (2016). Pengukuran Efisiensi dan Efektivitas Pengelolaan Keuangan Daerah pada Dinas Pengelola Keuangan, Pendapatan dan Aset (DPKPA) Kabupaten Minahasa Selatan. Jurnal EMBA, 4(1), 613622.

Papina, A., \& Aisyah, M. N. (2016). Audit Manajemen Untuk Menilai Efektivitas Atas Fungsi Sumber Daya Manusia Pada Lottemart Wholesale Yogyakarta. Jurnal Profita: Kajian Ilmu Akuntansi, 4(3), 1-15. Retrieved from http://journal.student.uny.ac.id/ojs/ojs/index.php/profita/article/view/5624

Perangin-angin, Z., \& Ariyanto, D. (2017). Pengaruh Sasaran Audit Manajemen Sumber Daya Manusia Terhadap Kinerja Karyawan. E-Journal Akuntansi Universitas Udayana, 21(3), 1993-2020.

Prasad, D. V. D., \& Babu, N, K. (2017). Human Resource Audit - An Overview. Journal of Advance Management Research, 05(05), 26-37.

Rochman, M. N., Andini, R., \& Oemar, A. (2016). Pengaruh Time Pressure, Resiko Audit, Materialitas, Prosedur Review Dan Kontrol Kualitas, Locus Of Control Serta Komitmen Profesional Terhadap Penghentian Prematur Atas Prosedur Audit (Studi Empiris Pada Kap Semarang). Jurnal of Accounting, 2(2).

Saleem, F., \& Akbar, W. (2015). Evaluation the Role of HR AUDIT in Organization Effectiveness: (Evidence from Banking Sector in KarachiPakistan). European Journal of Business and Management, 7(22), 149-162.

Schuler, R., \& Jackson, S. E. (2014). Human resource management and organizational effectiveness: yesterday and today. Journal of Organizational Effectiveness: People and Performance, 1(1), 35-55. https://doi.org/10.1108/JOEPP-01-2014-0003

Shiri, S. (2012). Strategic Role of HR Audit in Organizational Effectiveness. Journal of Management \& Public Policy, 3(2), 39-45.

Siregar, S. (2010). Statistika Deskriptif untuk Penelitian : Dilengkapi Perhitungan Manual dan Aplikasi SPSS Versi 17. Jakarta: PT Rajagrafindo Persada.

Sugiyono. (2016). Metode Penelitian Administrasi. Bandung: CV Alfabeta.

Sumenge, A. S. (2013). Analisis Efektifitas dan Efisiensi Pelaksanaan Anggaran Belanja Badan Perencanaan Pembangunan Daerah (Bappeda) Minahasa Selatan. Jurnal EMBA, 1(3), 74-81. 
Tan, C. L., \& Nasurdin, A. M. (2011). Human resource management practices and organizational innovation: Assessing the mediating role of knowledge management effectiveness. Electronic Journal of Knowledge Management, $9(2), 155-167$.

Ukil, M. I. (2015). Essence of Human Resource Audit: An Analytical Study. Journal of Management and Science, 5(1), 101-110. Retrieved from http://jms.nonolympictimes.org/Articles/JMS-March-2015-Vol-5-No-1-Art10.pdf

Wulandari, E. R., Rasyidi, A., \& Rachman, A. (2017). Audit Manajemen dalam Menunjang Efektivitas dan Efesiensi Kinerja atas Fungsi Penjualan pada PT. Aldik Sejahtera Bersama. Jurnal Ekonomi Akuntansi Universitas Bhayangkara, 3(3), 444-458. 